\title{
Mortality of olive ridley turtles Lepidochelys olivacea due to incidental capture in fishing nets along the Orissa coast, India
}

\author{
B. Pandav, B. C. Choudhury and C. S. Kar
}

The coastal state of Orissa, India, harbours three important mass-nesting beaches of the olive ridley sea turtle Lepidochelys olivacea. During a survey of sea turtle nesting beaches from December 1993 to May 1994, 5282 dead olive ridleys were counted along the $480 \mathrm{~km}$ coastline of Orissa. Almost all the deaths were due to incidental capture in offshore fishing nets. Increased fishing activities in the coastal waters near important sea-turtle nesting beaches pose a serious threat to the survival of this endangered sea turtle. It is therefore suggested that coastal waters adjacent to major sea-turtle nesting beaches be declared as closed areas for commercial fishing activities in order to ensure the sea turtle's long-term survival.

\section{Introduction}

Most species of sea turtles have suffered an alarming world-wide decline in numbers. Although none has become extinct in modern times, species such as Kemp's ridley Lepidochelys kempii, green turtle Chelonia mydas, hawksbill turtle Eretmochelys imbricata, olive ridley Lepidochelys olivacea and leatherback Dermochelys coriacea are now endangered. Sea turtles are often affected by factors other than direct exploitation from nesting beaches and coastal waters, or disturbance of nesting areas. Incidental or accidental capture in fishing nets is now emerging as a growing global problem. Pritchard (1976), Hillestad et al. (1978) and Hillestad et al. (1982) reviewed the impact of incidental capture on Kemp's ridley, loggerhead Caretta caretta and green turtle populations. While the death of sea turtles due to incidental capture has been well documented in coastal waters of Australia, South America, Central America and North America (Hillestad et al., 1982; Robins, 1995), very little quantified information is available on this aspect from the Indian coast.

Five species of sea turtles-olive ridley, green, hawksbill, leatherback and loggerhead - occur in Indian coastal waters and around the Bay of Bengal islands, and all are protected by Schedule 1 of the Indian Wildlife Protection Act, 1972. All but the loggerhead have been reported from Orissa (Dash and Kar, 1990). However, only one species, the olive ridley, has been confirmed as nesting in Orissa (Dash and Kar, 1990; Pandav et al., 1994).

A significant portion of the olive ridley sea turtle population that migrates to the Indian coast every year nests along the $480 \mathrm{~km}$ of Orissa's coast, which harbours three massnesting beaches, including the world's largest known nesting aggregation of olive ridleys at Gahirmatha (Bustard, 1976; Bustard and Kar, 1981; Kar, 1982; Dash and Kar, 1990; Pandav et al., 1994). Olive ridleys arrive in the coastal waters off Orissa during September and October but it is not known where they come from. Mating takes place in the shallow coastal waters off Gahirmatha during November and December followed by sporadic and mass nesting from January to April. An estimated half-a-million ridleys lay their eggs during these arribadas (Spanish for 


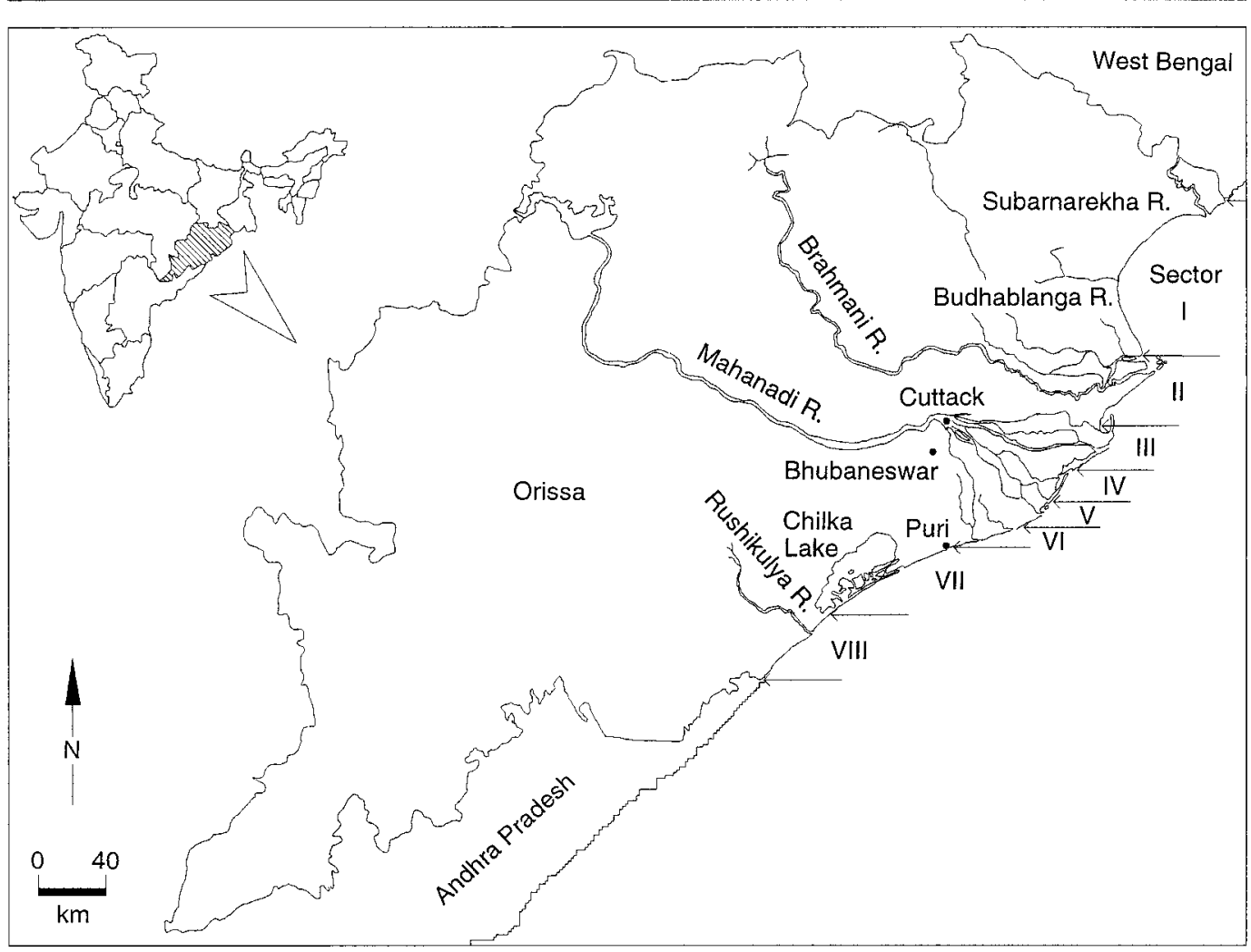

Figure 1. Orissa coast divided into eight survey sectors based on its physiography.

arrival) at Gahirmatha, which usually takes place twice in a season (Dash and Kar, 1990).

The illegal capture and transport of olive ridleys from the nesting beaches of Orissa to Calcutta and other markets were reported by Kar and Bhaskar (1982) and by Silas et al. (1983). Although the Gahirmatha nesting beach is now well protected by the Orissa Forest Department, the coastal waters off Gahirmatha are still subjected to heavy commercial fishing activities (Pandav et al., 1994). Large-scale mortality of olive ridleys due to incidental capture in fishing nets during the nesting season at Gahirmatha has also been documented (Kar, 1980; Silas et al., 1983; James et al., 1989; Dash and Kar, 1990). This paper describes the details of dead sea turtles found along the Orissa coast during a survey of sea turtle nesting beaches from December 1993 to May 1994.

\section{The Orissa coast}

The $480-\mathrm{km}$ coastline of Orissa stretches from east of the Subarnarekha River near Udayapur village (bordering West Bengal) in the northeast to the marshes of Ichhapuram (bordering Andhra Pradesh) in the south. Six districts (Balasore, Bhadrakh, Kendrapara, Jagatsinghpur, Puri and Ganjam) adjoin the sea. The major rivers that flow into the Bay of Bengal in Orissa are the Subarnarekha, Budhabalanga, Brahmani-Baitarani (Dhamra), Mahanadi, Devi and Rushikulya. Several smaller rivers (e.g. Hansua, Kadua, Kushabhadra and Bahuda) also drain into the Bay. There are three off-shore islands (the Shorts and the Wheeler Islands) located at the mouth of Rivers Brahmani-Baitarani.

One conspicuous feature of the vegetation of the Orissa coast is Casuarina spp. (mostly Casuarina equisitifolia), which has been planted 
on a massive scale to prevent beach erosion and to shelter the coast from cyclones. Natural beach vegetation include the psammophytes (e.g. Spinifex littoreus, Ipomea pescaprae, Launea sarmentosa and Gisekia phranacoides). Besides these, mangrove vegetation occurs near the Brahmani-Baitarani and Mahanadi estuaries.

\section{Methods}

The entire Orissa coast was surveyed four times, once by foot and three times by bicycle between December 1993 and May 1994 to monitor turtle nesting activities. To enable systematic coverage, the coastline was divided into eight sectors based on major physiographical features, such as estuaries, sandspits, bays and other coastal landmarks (Figure 1). A total count was made of the dead sea turtles washed up in each sector. Dead turtles were marked on their carapaces with white paint and were dragged up the beach to avoid repeat counting during the next survey. The turtles were sexed, using external characters. Males were characterized by the presence of a long tail, which extends much beyond the posterior end of the carapace, and the strongly curved claw on the fore-flipper. Females had shorter tails, extending little beyond the carapace, with a small and straight claw on the fore-flipper. In case of decomposed turtles, the

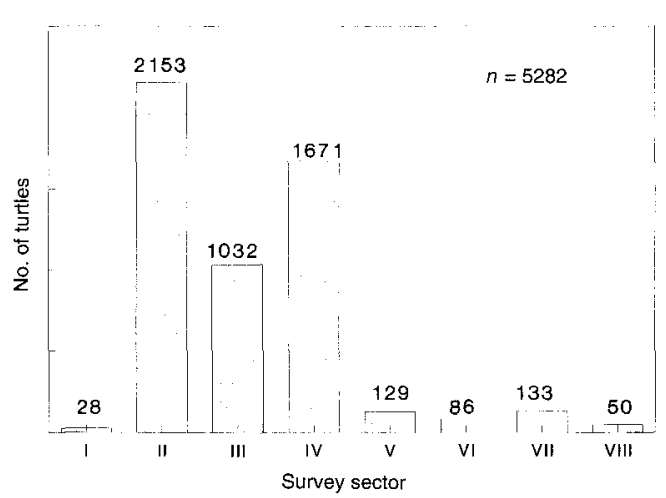

Figure 2. Number of dead olive ridley turtles counted by sector along the Orissa coast from December 1993 to May 1994. claw character of the fore-flipper was used to determine the sex. Whenever possible the cause of death was determined from the external injuries observed on the heads and carapaces.

\section{Results and discussion}

All the dead turtles counted during the surveys were adult olive ridleys, with the curved carapace length varying from 68 to $76 \mathrm{~cm}$. A total of 5282 turtles was counted, with 1436 (27.2 per cent) being male and 3846 (72.8 per cent) female (Figure 2). Gahirmatha, Paradeep and Kujang (sectors II, III and IV, respectively) together accounted for 92 per cent of the total number of dead turtles, with Gahirmatha having the most (2153).

In addition to our surveys, dead turtles were recorded along the Gahirmatha coast between September 1993 and April 1994 by the personnel of Gahirmatha Marine Turtle Research Centre (GMTRC; Figure 3). The number of dead turtles started increasing after the last week of December and reached a peak during January along the entire Orissa coast. The number of dead turtles stranded on the shore decreased after February and was lowest in April.

Large-scale mortality of olive ridleys along the Gahirmatha coast was also reported by

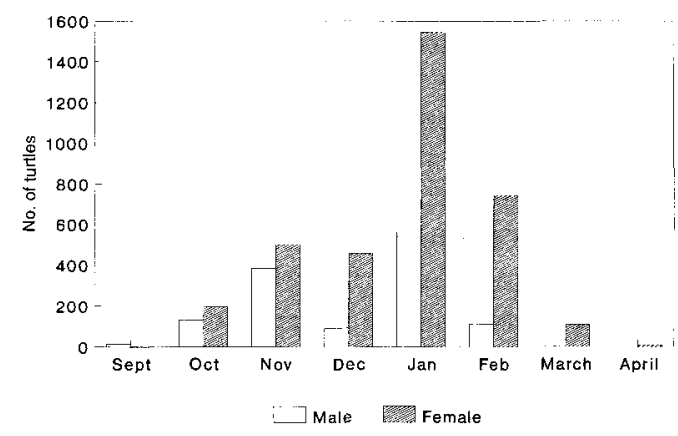

Figure 3. Number of dead olive ridley turtles counted along the Gahirmatha (sector II), Paradeep (sector III) and Kujang (sector IV) coast during the 1993-94 nesting season by GMTRC personnel and the survey team. 
Kar (1980), Silas et al. (1983), James et al. (1989), Dash and Kar (1990). James et al. (1989) reported a large number of olive ridley carcasses (7500) during the 1983 nesting season at Gahirmatha and attributed this to incidental capture in fishing gear. The large-scale mortality in the 1993-94 nesting season was also due to turtles becoming entangled in fishing gear. Once entangled they die from suffocation or are beaten to death by boat-men for easy removal from the net. The injuries on heads and carapaces provided ample evidence of this.

In sectors II, III and IV, where the largest numbers of dead turtles were recorded, there is a large-scale trawler fishery. Trawlers from Paradeep, Dhamra and Chandipur operate along these three areas (Table 1). The coastal waters off Gahirmatha and adjacent areas are relatively shallow and are mating grounds for olive ridleys. The coexistence of a large number of turtles with large-scale trawling near the shore results in high turtle mortality. This situation will be aggravated in the future with the Government's decision to open a recently constructed fishing jetty with the capacity to harbour 500 trawlers at Talchua near the Dhamra estuary. This jetty is only $10 \mathrm{~km}$ east of Gahirmatha.

Although the number of mechanized boats operating in the Balasore coast is greater than in other coastal districts of Orissa, only 28 dead olive ridleys were recorded along this coast between Chandipur and Digha (sector I). This low turtle mortality may be due to the absence of sea turtles in the coastal waters of Balasore, which is characterized by long stretches of intertidal zones. Dead turtles were observed from the mouth of the Devi River to the mouth of Rushikulya River (sectors VVII). However, no turtles were found along the coast from Gopalpur to Patasonapur village bordering Andhra Pradesh (sector VIII). While it is difficult to give any conclusive reason for the absence of dead sea turtles in this area, it is surmised that either they are not getting caught in nets or that entangled turtles are captured and taken by fishermen for consumption. Most of the marine fishing along this part of the coast is by traditional craft or catamarans. Unlike trawl nets and the nets in the mechanized fishing vessels, where the net is spread over a distance of $2-3 \mathrm{~km}$, the spread of traditional catamaran nets is much smaller and poses less of a threat to turtles. Fishermen in this area are of Telgu origin and they do consume turtle eggs and meat.

\section{Conclusions}

Large-scale mortality of breeding olive ridleys due to incidental catch during an arribada could have an adverse effect on their population. This has already occurred in the case of the Kemp's ridley turtle. Over a period of 30 years the number of nesting Kemp's ridley was reduced from 40,000 in 1947 to only a few hundred in 1995. Apart from the massive harvest of eggs and nesting females, this decline in number is attributed to high adult mortality in the 1960s and 1970s associated with a rapidly developing shrimp fishery (National Research Council, 1990). The same thing may

Table 1. Operation of mechanized fishing boats in various districts and sectors of Orissa

\begin{tabular}{llllll}
\hline Boat type & \multicolumn{2}{l}{ District and sector } & & & \\
\cline { 2 - 5 } & $\begin{array}{l}\text { Balasore } \\
\text { (I) }\end{array}$ & $\begin{array}{l}\text { Cuttack } \\
\text { (II, III, IV) }\end{array}$ & $\begin{array}{l}\text { Puri } \\
\text { (V, VI, VII) }\end{array}$ & $\begin{array}{l}\text { Ganjam } \\
\text { (VII) }\end{array}$ & Total \\
\hline Wooden trawler & 125 & 273 & 60 & Nil & 458 \\
Gill-netter & 601 & 32 & Nil & Nil & 633 \\
Motorized country craft & 718 & 752 & 315 & 57 & 1842 \\
Motorized catamaran & Nil & 20 & 25 & Nil & 45 \\
Total & 1444 & 1077 & 400 & 57 & 2978 \\
\hline
\end{tabular}

(C) $1997 \mathrm{FFl}$, Oryx, 31 (1), 32-36 
happen to the olive ridley at Gahirmatha if adequate steps are not taken to mitigate this incidental capture.

Olive ridleys arrive along the Orissa coast by late September or early October and stay till the end of April. During this period, mating takes place in the shallow coastal waters followed by sporadic and mass nesting. In order to minimize the incidental capture in fishing nets, areas having a high concentration of sea turtles during the breeding season (October-April) such as off-shore waters of Gahirmatha, Paradeep and Devi, should be declared as no-fishing zones. However, studies on the distribution of olive ridley in the coastal waters along these three areas during the breeding season is essential to demarcate the no-fishing zone.

For the trawlers operating along the rest of Orissa coast the incidental capture could be reduced by the introduction and use of Turtle Excluder Devices (TEDs), which were developed in the USA for shrimp trawlers. These devices allow trapped turtles to escape while the fish catch is retained in the net. Use of TEDs should be made mandatory for the trawlers operating along the Orissa coast. The initiative should come first from the government, either from the Ministry of Commerce or the Ministry of Environment, by making TEDs available on subsidy through the Marine Products Export and Development Authority or State Fisheries Department and by encouraging the fishermen to use them through an extension programme.

\section{Acknowledgements}

The authors gratefully acknowledge The Director, Wildlife Institute of India, for providing the funds to carry out the survey, and the Orissa State Forest Department for providing the logistic support during the fieldwork.

\section{References}

Bustard, H.R. 1976. World's largest sea turtle rookery? Tiger Paper, $3,3$.

Bustard, H.R. and Kar, C.S. 1981. Annual nesting of the Pacific Ridley sea turtle (Lepidochelys olivacea) in Orissa, India. Brit. J. Herpetology, 6, 139.
Dash, M.C. and Kar, C.S. 1990. The Turtle ParadiseGahirmatha. Interprint, New Delhi.

Hillestad, H.O., Richardson, J.I. and Williamson, G.K. 1978. Incidental capture of sea turtles by shrimp trawler men in Georgia. Proceedings of the Annual Conference of the Southeast Association of Fish and Wildlife Agencies, 23.

Hillestad, H.O., Richardson, J.I., Mcvea, C. Jr. and Watson, J.M. Jr. 1982. World wide incidental capture of sea turtles. In Biology and Conservation of Sea Turtles (ed. K. A. Bjorndal), pp. 489-495. Smithsonian Institution Press, Washington DC.

James, P.S.B.R., Rajagopalan, M., Dan, S.S., Fernando, A.B. and Selvaraj, V. 1989. On the mortality and stranding of marine mammals and turtles at Gahirmatha, Orissa from 1983 to 1987. J. Mar. Biol. Ass. India, 31 (1 \& 2), 28-35.

Kar, C.S. 1980. The Gahirmatha turtle rookery along the coast of Orissa, India. IUCN/SSC Marine Turtle Newsletter, 15, 2-3.

Kar, C.S. 1982. Discovery of second mass nesting ground of the Pacific olive ridley sea turtles (L. olivacea) in Orissa, India. Tiger Paper, 9 (1), 6-7.

Kar, C.S. and Bhaskar, S. 1982. The status of sea turtles in the Eastern Indian Ocean. In The Biology and Conservation of Sea Turtles (ed. K. A. Bjorndal), pp. 365-372. Smithsonian Institution Press, Washington DC.

National Research Council. 1990. Decline of the Sea Turtles: Causes and Prevention. National Academy Press, Washington DC.

Pandav, B., Choudhury, B.C. and Kar, C.S.1994. A Status Survey of Olive Ridley Sea Turtle (Lepidochelys olivacea) and its Nesting Habitats along the Orissa Coast, India. Wildlife Institute of India, Dehradun.

Pritchard, P.C.H. 1976. Endangered species: Kemp's ridley turtle. Florida Naturalist, 49, 15-19.

Robins, J.B. 1995. Estimated catch and mortality of sea turtles from the East Coast Trawl Fishery of Queensland, Australia. Biological Conservation, 74, 157-168.

Silas, E.G., Rajagopalan, M., Fernando, A.B. and Dan, S.S. 1983. Marine turtle conservation and management. A survey of the situation in Orissa 1981-82 and 1982-83. Mar. Fish. Infor. Serv. T $\mathcal{E} E$ Ser. 50, 13-23.

Bivash Pandav*, Wildlife Institute of India, PO Box 18, Dehradun-248001, Uttar Pradesh, India ( ${ }^{*}$ Address for correspondence: House No. 25 Dharmavihar, Jagamara, Bhubaneswar-751030, Orissa, India.

B. C. Choudhury, Wildlife Institute of India, PO Box 18, Dehradun-248001, Uttar Pradesh, India.

C. S. Kar, Research Officer, Office of the D.F.O., At \& P.O. Rajinagar, Dist Kendrapara, Orissa, India. 